\title{
THE PECULIARITIES OF MENTAL DEVELOPMENT IN PRESCHOOL CHILDREN WITH ATTENTIVE DEFICIENCY SYNDROME WITH HYPERACTIVITY
}

https://doi.org/10.37096/SHDISJ-20-1.1-0002

Knyazev V. https://orcid.org/0000-0001-9599-7429

\begin{abstract}
Annotation
The article is devoted to the analysis of the peculiarities of the early manifestations of attention deficit with hyperactivity disorder (ADHD) in preschool children. The topic of ADHD requires a detailed psychological analysis. Such work will allow the formation of methodological and theoretical tools, the need for which is now felt by the practical psychologists. The following research methods have been used: theoretical analysis, generalization of scientific approaches, theoretical modeling, symptomatic analysis. Based on the data obtained, a unified theoretical and methodological model has been developed that allows to carry out the comprehensive analysis of the developmental features of preschool children.

The analysis of the developmental features of the child in the early stages of ontogenesis can be carried out along several axes, which go through several stages of their formation, which are accompanied by dynamic changes such as interfunctional relationships and the child's worldview is shown. A comparison of the results of studies of the features of the early stages of children development with ADHD has allowed to expose a deficit axis of development, changes in the formation of which lead to the appearance of children's behavioral disorders of such a group. The peculiarities of the passage of the axes development in the process of ontogenesis also makes it possible to identify the mechanisms of their correction and habilitation, which has undoubted practical value. At the moment, this integrative model has already shown its practical value. A number of correctional development programs, as well as support programs, have been worked out. The results of empirical studies show their high efficiency. In addition, the model demonstrates its high efficiency in advising family members and child support groups, in particular, when conducting psycho-educational work.

Key words: attention deficit hyperactivity disorder, diagnosis, integrative model, psychological correction methods, preschool age, early intervention.

\section{Introduction}

Being one of the most common problems of childhood development, attention deficit hyperactivity disorder is a comorbid disorder characterized by a combination of a large number of various symptoms. Moreover, various approaches aimed at correcting and abilitating developmental deficiencies interpret the

causes of this symptomatology in different ways, often using descriptive models that are different from each other. However, practical experience shows the need to describe the developmental features of children with ADHD from the standpoint of a single theoretical and methodological model that can integrate existing data into itself, while remaining open for further
\end{abstract}


"SOCIALIZATION \& HUMAN DEVELOPMENT" INTERNATIONAL JOURNAL

changes. Such a model can be built only on the basis of a thorough analysis of the existing at the time data on the causes and characteristics of the manifestation of ADHD symptoms in children of different age and social groups.

According to existing data, manifestations of pathological symptoms in children with attention deficit hyperactivity disorder are especially intense in periods from 5 to 10 years, which corresponds to the initial stages of a child's schooling, as well as from 12 to 15 years (Rumyantseva V. M. 2003). However, the first manifestations of this symptomatology can be fixed already in the younger preschool age. However, during infancy, as well as in the preschool period, the pathological symptoms characteristic of children with ADHD manifest themselves in a slightly different way. In children, sleep disturbance, difficulties in interacting with various sensory stimuli, which manifest themselves as hypo- and hypersensitivity, motor awkwardness, a slight delay in speech development, are observed (Bundy A. 2017). Moreover, in children of primary school age, the symptoms of ADHD may coexist with asthenic manifestations, which are combined with various learning difficulties (Sirotyuk A.L. 2002). This heterogeneity of symptoms at different stages of the development of a child with ADHD is interpreted differently within the framework of biomedical and sociopsychological models, leading to insufficient consideration of various factors in the organization of correctional work.

The relevance of the request for the development of a unified model that allows us to describe the child's development process taking into account possible developmental deficiencies is increasing due to the need for an environmentally valid and effective corrective and therapeutic intervention. Without pretending to paradigm, the proposed theoretical and methodological model is designed to facilitate the process of practical work of specialists in the field of psychological correction, rehabilitation and consultation.

The object of the study: child development.

The subject of the study: the regularities of the formation of higher mental functions of HMF in pre-school children with attention deficit hyperactivity disorder (ADHD).

The purpose of the study is a theoretical analysis of the researches of the symptoms development of ADHD in preschool children; theoretical analysis of existing periodizations of the development of the psyche in ontogenesis; the formation of an integrative theoretical and methodological model; comparing the data obtained on the features of the early manifestation of symptoms of ADHD with the stages of the development of the psyche in ontogenesis; the exposure of the main directions of corrective intervention during the work of ADHD in pre-school children.

The research methods: theoretical analysis of the mental development of preschool children with ADHD; generalization of V.V. Lebedinsky, D. B. Elkonin, J. Piaget's scientific approaches describing the characteristics of the development of the psyche in ontogenesis; theoretical modeling of an integrative approach to the analysis and correction of ADHD; symptomatic analysis of the manifestations of attention deficit hyperactivity disorder in pre-school children. 
"SOCIALIZATION \& HUMAN DEVELOPMENT" INTERNATIONAL JOURNAL

At this moment ADHD is one of the most common disorders in childhood. According to the studies, the symptomatology characteristic of this syndrome is observed in approximately 2 $18 \%$ of children (Rowland, Lesesne, \& Abramowitz, 2002). Early manifestations of such symptoms can lead to significant behavioral difficulties, which in turn can become an obstacle to the development of academic and social skills. In addition, neuropsychological deficits characteristic of this group of children can lead to underdevelopment of regulatory processes, which, in turn, are a necessary component in the structure of any higher mental function (Semenovich A.S., 2002).

In most cases, the diagnosis of ADHD is given to children of primary school age, and, most likely due to reinforcement in pathological manifestations against the background of a sharp increase in workloads, difficulties in organizing work in the classroom, which is exacerbated by a lack of understanding of the causes of problem behavior by teachers, parents and the child himself/herself.

According to the studies of children with ADHD symptoms in the pre-school period, the levels of inattention, as well as manifestations of hyperactivity / impulsivity are often high, but there is significant variability with respect to the symptoms peculiarities in children (Lahey BB, Lee SS, Sibley MH, et al., 2016). In particular, it was shown that the intensity of pathological manifestations decreased with age, however, such a feature was more characteristic of symptoms of inattention than manifestations of impulsivity and hyperactivity.

The results of the studies by Leopold et al., show (Leopold DR, Christopher M.E, Burns G.L et al., 2016) similar results.
However, in the framework of this study, a decrease in the degree of intensity of the symptoms of hyperactivity was revealed, while the severity indicators for the symptoms of inattention remained unchanged.

The significant difficulty in researching the features of the early manifestations of ADHD is due to the fact that such behavioral features as a high level of motor activity, impulsivity, difficulty with maintaining and switching attention are normative manifestations for preschool children. The studies in this area show that in pre-school age for children with attention deficit hyperactivity disorder concomitant disorders are also typical. One of the most common is oppositional disorder, anxiety disorder, and communication disorder (Egger, et al., 2006; Posner, et al., 2007). The latter is of particular interest, since it is through interaction with the socio-cultural environment in the process of ontogenesis the gradual formation of higher mental functions occurs, which at the time of birth are present in the child only in the form of potential for development (L.S. Vygotsky, 2005). It has been shown that children with ADHD have difficulty constructing a communication act due to the insufficient amount of information they provide during the interaction (Nilsen et al., 2015), as well as difficulties in organizing the interaction process taking into account the social context (Landau and Milich, 1988). In addition, it has been shown that children with ADHD experience significant difficulties in understanding social cues and emotional distinction, even more significant than children with autism spectrum disorders (Downs and Smith, 2004). To this it is worth adding outbreaks of aggression and difficulty maintaining the 
"SOCIALIZATION \& HUMAN DEVELOPMENT" INTERNATIONAL JOURNAL

distance during the interaction, which are often observed in children with hyperactivity and attention deficit.

The data about the peculiarities of the development of cognitive sphere in children with problems of attention and motor disbraking show that differ psychological functions in pre-school period suffer insignificantly. The main reason of slow information memorizing, complication with keeping attention is the problems of arbitrary activity. (L. S. Vigotsky, I. I. Kravtsova, I. L. Horlova, et all). There is little data on the features of the development of the motivational sphere and game activity in this category of children, however, it can be supposed difficulties with behaviour regulation and keeping attention which lead to instability, hamper the development of the game activity. Such developmental features can be further enhanced by peer rejection (Landau et al., 1998).

Thus, despite the significant variability in the symptoms of ADHD in pre-school age, as well as the difficulty of identifying them in children of this age group, difficulties in controlling behavior and inattention can be identified as the main markers of pathological symptoms (Barkley, 1997). However, the additional deficits that often accompany ADHD in the pre-school period are also of considerable interest, as they may indicate additional ways of influence when organizing corrective work. For this purpose, it is necessary to compare the obtained data with the main stages and features of the development of the psyche in ontogenesis. Such work seems more productive if there is a single integrative model of the development of the psyche in ontogenesis.

To form a single integrative model of child development, three periodizations of child development have been analyzed. As the initial periodizations have been selected:

1. Periodization of levels of emotional development according to V.V. Lebedinsky

2. Periodization of intellectual development by J. Piaget

3. Periodization of mental development according to D.B Elkonin.

For the analysis and subsequent integration, the stages of the above periodizations of development corresponding to the age period from 0 to 7 years have been distinguished. As a result of the analysis, three integrative levels of development have been identified, where all data on the characteristics of the development of the child have been grouped in four axes:

1. Axis A - regulatory processes

2. Axis B - cognitive processes

3. Axis $\mathrm{C}$ - leading motivation

4. Axis D - relation to the world

The first level covers the time period from 0 to 1 year. The following periods from the analyzed development models correspond to it:

1. Model levels of emotional development according to V.V. Lebedinsky:

- level of assessment of the intensity of environmental impacts;

- level of affective stereotypes.

2. Periods of intellectual development according to J. Piaget:

- stage of sensorimotor intelligence (private stages 1$3)$. 
"SOCIALIZATION \& HUMAN DEVELOPMENT" INTERNATIONAL JOURNAL

3. Development levels for the periodization of the mental development of D. B. Elkonin:

- the era of early childhood.

The second level covered the period from 1 year to 3 years. It is corresponded with:

1. Model levels of emotional development according to V.V. Lebedinsky:

- level of affective expansion;

- level of affective attachment.

2. Periods of intellectual development according to J. Piaget:

- stage of sensorimotor intelligence (private stages 46).

3. Development levels for the periodization of the mental development of D. B. Elkonin:

- the era of early childhood.

The third level corresponds to a time period of 3 to 7 years. It is corresponded with:
1. Model levels of emotional development according to V.V. Lebedinsky:

- the level of symbolic regulation of emotional processes.

2. Periods of intellectual development according to J. Piaget:

- stage of preoperative thinking.

3. Development levels for the periodization of the mental development of D. B. Elkonin:

- the era of childhood.

The results obtained by grouping the data along the axes are presented in the tab 1.

In the proposed table, the axes $\mathrm{B}, \mathrm{C}$, and $\mathrm{D}$ are intrapsychic, and show the process of gradual formation in ontogenesis of the main structural components of the child's psyche. Axis A is more relevant to the extrapsychic level and shows how the nature of the interaction between the child and the world changes in the process of individual development. 
"SOCIALIZATION \& HUMAN DEVELOPMENT" INTERNATIONAL JOURNAL

Table 1.

Stages of the development of the psyche in ontogenesis

\begin{tabular}{|c|c|c|c|c|}
\hline & Axis A & Axis B & Axis $\mathrm{C}$ & Axis D \\
\hline 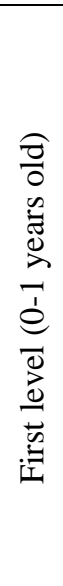 & $\begin{array}{l}\text { regulation of emotional } \\
\text { and physical states } \\
\text { through interactions with } \\
\text { the parent; } \\
\text { self-regulation of own } \\
\text { states due to cyclically } \\
\text { repeating rhythmic } \\
\text { patterns; } \\
\text { formation of an optimal } \\
\text { level of activation due to } \\
\text { the integration of } \\
\text { multimodal sensory } \\
\text { signals. }\end{array}$ & $\begin{array}{l}\text { assessment of sensory } \\
\text { influences on the } \\
\text { principle of "many-few"; } \\
\text { reflex integration; } \\
\text { basic motor skills; } \\
\text { breeding goals and } \\
\text { means of it achieving. }\end{array}$ & $\begin{array}{l}\text { direct emotional } \\
\text { communication with an } \\
\text { adult. }\end{array}$ & $\begin{array}{l}\text { passive interaction with the } \\
\text { world, dependence on } \\
\text { sensory environmental } \\
\text { signals; } \\
\text { "Merging" of the child } \\
\text { with the mother; } \\
\text { fixation on the physical } \\
\text { and bodily aspects of the } \\
\text { self. }\end{array}$ \\
\hline 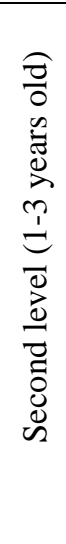 & $\begin{array}{l}\text { regulation of emotional } \\
\text { states and behavioral } \\
\text { patterns by the parent as } \\
\text { an external helping } \\
\text { object; } \\
\text { self-regulation of the } \\
\text { emotional state through } \\
\text { interaction with the } \\
\text { environment (according } \\
\text { to the principle of } \\
\text { emotional swing); }\end{array}$ & $\begin{array}{l}\text { assessment of } \\
\text { environmental impacts } \\
\text { on the basis of the "like- } \\
\text { dislike" principle; } \\
\text { the use of tools in } \\
\text { interaction with the } \\
\text { world; } \\
\text { interiorization and } \\
\text { combination of } \\
\text { previously mastered } \\
\text { behavioral and cognitive } \\
\text { patterns. }\end{array}$ & $\begin{array}{l}\text { interaction with the outside } \\
\text { world and objects as social } \\
\text { tools. }\end{array}$ & $\begin{array}{l}\text { the development of the } \\
\text { world around through } \\
\text { targeted interaction with it; } \\
\text { increase the degree of } \\
\text { separation of the child; } \\
\text { fixation on environmental } \\
\text { objects. }\end{array}$ \\
\hline 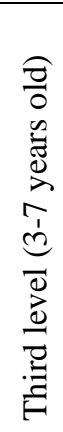 & $\begin{array}{l}\text { self-regulation of } \\
\text { emotional states through } \\
\text { game activity; } \\
\text { internalization of norms } \\
\text { and rules of behavior in } \\
\text { society. }\end{array}$ & $\begin{array}{l}\text { formation of a system of } \\
\text { integrated actions } \\
\text { (operations); } \\
\text { development of the } \\
\text { ability to generalize and } \\
\text { categorize; } \\
\text { forming an image of } \\
\text { yourself and an internal } \\
\text { picture of the world. }\end{array}$ & role-playing game. & $\begin{array}{l}\text { interaction with the world } \\
\text { indirectly by a system of } \\
\text { norms and rules of } \\
\text { behavior; } \\
\text { world as an "information } \\
\text { space". }\end{array}$ \\
\hline
\end{tabular}

Based on the data given in the table, an integrative model for the development of a pre-school child has been formed (Figure 1). 


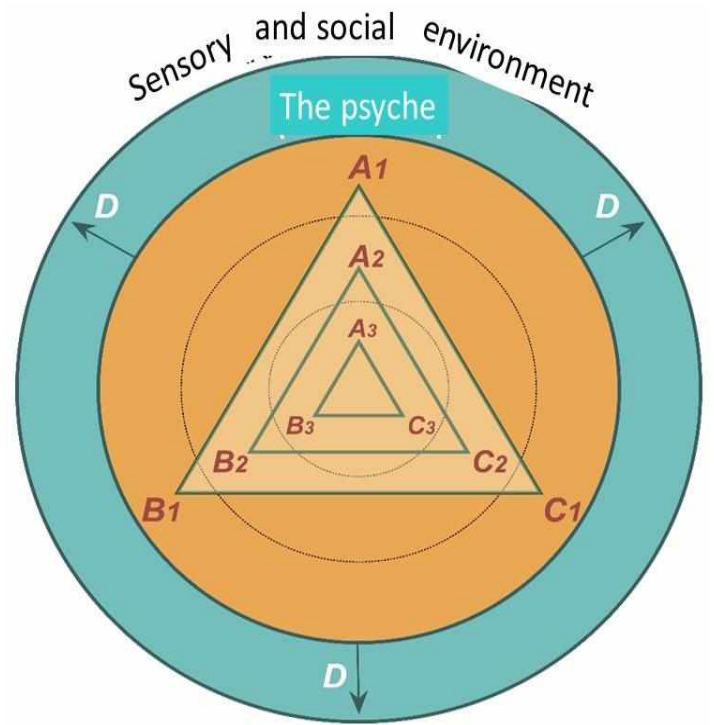

Note: A1, A2, A3 - symbols of the regulatory axis, respectively, the features of its development at various stages of ontogenesis.

B1, B2, B3 - symbols of the cognitive axis, respectively, the features of its development at various stages of ontogenesis.

C1 C2 C3 - symbols of the motivational axis, respectively, the features of its development at various stages of ontogenesis.

D - axis of the relationship of the child to the world

Fig. 1 Integrative model of a pre-school child development

This model is based on the categorical net of modern scientific knowledge. As the main meta-ontological categories on which the network model is based, one can pick out (M. M. Semago, N. Ya. Semago, 2011 p. 18):

- triad analysis;

- synchronism (dynamic harmony) of all forming, developing structures;

- fractality (self-similarity, holography) of analyzed constructs;

- measure (nature and dynamics of structural changes in the system and its elements).

Taking into account the principles of formation of $\mathrm{HMF}$ in ontogenesis, proposed by L.S. Vygotsky, as well as the data given in the table, three stages in the development of the psyche of pre-school children have been identified:

\section{Sensory-power}

- $\quad$ significant dependence on signals of sensory environmental influences;

- fixation on the body and its reactions;

- regulation of the intensity of sensory signals;

- external loci of behavior control;

- fixed rhythmic complexes;

- regulation of visceral processes;

- energy supply and involuntary regulation.

2. An affective-behavioral

- the formation of detailed behavioral patterns;

- affective interpretation of environmental influences;

- interaction with external objects, as with social tools;

- purposeful behavior;

- expansion of the emotional repertoire.

3. Cognitive regulatory 
"SOCIALIZATION \& HUMAN DEVELOPMENT" INTERNATIONAL JOURNAL

- self-regulation through the operation of images and symbols;

- formation of an internal locus of control;

- cognitive information processing;

- data integration of lower levels;

- orientation to the information space.

In figure 1 it is shown how the selected stages are related to the regulatory (A), cognitive (B), motivational (C) axes, which belong to the intrapsychic space, as well as the extrapsychic axis (D), which characterizes the changes in the child's attitude to the world and is determined by a set of indicators of the first three axes. In the form of a formula, it can be represented as follows $\mathrm{D}=(\mathrm{A}+\mathrm{B}+\mathrm{C})$ : 3 . Thus, the changes in the development of one of the intrapsychic axes will lead to a disruption in the process of implementing leading activities by the child, which in turn can lead to a disruption in the process of interaction of the child with the world. Based on this, it can be assumed that in the process of comparing the current level of development with indicators on each axis, taking into account the main stages of their formation, it is possible to identify the area of main deficit.

In addition, when the theory of dissipative systems is taken into account, in the context of its consideration by psychological science, the proposed theoretical and methodological model makes it possible to influence the most preserved development axes, if it is impossible to stabilize the deficient axis, or in parallel with this. It is due to the following features of the psyche as a complex system (Zinchenko Yu.P., 2012; Klochko V.E., 2013):

- openness;
- constant interchange with the environment;

- disequilibrium state;

- the need for external influence to change its state.

\section{Discussion}

The described approach potentially appears to be much more effective than the models that individual psychological schools offer. Based on the data on the peculiarities of development of HMF functions in ontogenesis and proposing for analysis 4 axes of the child's development, it allows overcoming the conflict between psychosocial and biologizing models of ADHD (Frances A., 2016), supplementing the available data on the influence of biological and social factors with a model exclusively psychological, which suggests both the importance of the process of interaction of the child with the environment, and biological factors. A similar model also implies the possibility of revealing the structure of a defect by comparing the level of development of both the intrapsychic and extrapsychic axes. In addition, it becomes possible to identify the trajectories of the development of symptoms taking into account age-related dynamics (Biederman J, Mick E, Faraone S.V., 2000), identifying the area of actual and immediate development. It makes possible to effectively introduce non-drug methods of stabilizing the child's condition, which are recommended as the most desired pre-school children (Fiks A.G, et al, 2016). Given the multifactorial nature of the ADHD problem in childhood, an approach that allows us to analyze the individual characteristics of the "developmental drama" of a child, taking into account its individual and personality characteristics, seems to be potentially more effective than methods designed to 
"SOCIALIZATION \& HUMAN DEVELOPMENT" INTERNATIONAL JOURNAL

work with groups (Edward G. Feil, et al, 2016).

On the basis of the proposed integrative scheme, correctional and developmental programs for children with ADHD of preschool age are developed. In the process of such work, the model has showed its significant practical value, acting as a support in analyzing the structure of the defect, identifying targets and goals when writing correction programs, conducting psycho-educational work with family members and educators.

There is no doubt that the theoretical analysis which has been proposed here requires studies showing the effectiveness of this model in its practical application. The model requires further development and additions, through analysis of research results of developmental features and the use of various methods of non-drug correction, when working with attention deficit hyperactivity disorder in pre-school children. Also, as a promising direction for the development of the proposed model, the integration of the elements of the neuropsychological model, with their translation into the language of developmental psychology comes forward. In particular, the concept of a neuropsychological factor, symptom, syndrome, the concept of irregular development, and a number of others may be of interest. The model of the neuropsychological factor with its hierarchy, features of vertical and horizontal organization, division into "rigid" and "flexible" links, as well as its definition as a modus operandi of individual mental processes, is of most interest here. The integration of this concept seems to be the most obvious of the following steps to improve the integrative model.

\section{Conclusions}

The comparison of data on the developmental peculiarities of children with ADHD in the pre-school period with an integrative psyche developmental scheme in ontogenesis gives us the opportunity to identify the main levels and areas of work in organizing the correction.

In this case, axis A acts as the main target of correction, its components at the sensory-energy level. This deficit, most likely, leads to secondary deficits of the B and $\mathrm{C}$ axes at an affectively behavioral level. The complex of primary and secondary defects leads to disruption of the process of interaction with the world.

The concept of allostasis (Sabbah W, Watt R.G, Sheiham A, Tsakos G., 2008) gives us the opportunity to move on to a new model for the organization of correction. This model indicates the possibility of obtaining positive changes in the condition of the child by affecting various components in the structure of the defect. This approach seems quite promising, as it allows you to organize work with the child, taking into account its individual characteristics, as well as the characteristics of the social development situation. Reliance on an integrative development scheme also allows not only to identify areas of impact, but also to identify areas of current and immediate development.

This topic requires further deep study. A promising direction for the further development of this topic is the creation on the basis of existing models of a unified integrated program for accompanying children with ADHD. 
"SOCIALIZATION \& HUMAN DEVELOPMENT" INTERNATIONAL JOURNAL

\section{References}

Bandy A. Sensornaia yntehratsyia / Anyta Bandy, Shelly Lein, Эlyzabet Miurrei;

per. [s anhl.] y nauch. Red. D.V. Ermolaeva. (2017). - M.: Terevynf. - 786 s. - ICBN 978-5-4212-0411-4. [in Russian]

Barkley RA. (1997). Behavioral inhibition, sustained attention, and executive functions: constructing a unifying theory of ADHD. Psychological Bulletin. 121:65-94.

Biederman J, Mick E, Faraone SV. (2000). Age-dependent decline of symptoms of attention deficit hyperactivity disorder: impact of remission definition and symptom type. Am J Psychiatry. 157: 816-18.

Downs A, Smith T. (2004). Emotional understanding, cooperation, and social behavior in high-functioning children with autism. J Autism Dev Disord. 34(6):625-635.

Edward G. Feil, Jason W. Small, John R. Seeley, Hill M. Walker, Annemieke Golly, Andy Frey, and Steven R. Forness. (2016). Early Intervention for Preschoolers at Risk for Attention-Deficit/Hyperactivity Disorder: Preschool First Step to Success. Behav Disord. 41(2): 95106.

Egger HL, Kondo D, Angold A. (2006). The epidemiology and diagnostic issues in preschool attentiondeficit/hyperactivity disorder: A review. Infants \& Young Children. 19(2):109-122.

Frances A. (2016). Entrenched reductionisms: The bête noire of psychiatry. History

Psychology, 19(1), $57-59$.
Fiks AG, Ross ME, Mayne SL, Song L, Liu W, Steffes J, et al. (2016). Preschool ADHD diagnosis and stimulant use before and after the 2011 AAP practice guidenline. Pediatrics. December; 138(6), pii: e20162025 Epub 2016 Nov 15

Klochko V.E. (2013). Problema soznaniya v psikhologii: postneklassicheskiy rakurs / V.E. Klochko // Vestnik Moskovskogo universiteta. Ser.14. Psikhologiya. - №12, 3-20. [in Russian]

Kuznetsova L. E.. Gladko V. V. (2016). Psikhologicheskiye osobennosti detey $\mathrm{s}$ sindromom defitsita vnimaniya i giperaktivnosti. usloviya ikh psikhokorrektsii // Molodoy uchenyy. — №7, 327-331. [in Russian]

Landau S., Milich R. (1988). Social communication patterns of attentiondeficit-disordered boys. J. Abnorm. Child Psychol. 16 69-81. 10.1007/BF00910501

Landau S, Milich R, Diener M. (1998). Peer relations of children with attention-deficit hyperactivity disorder. Reading and Writing Quarterly: Overcoming Learning Difficulties. 14 (1):83-105.

Lahey BB, Lee SS, Sibley MH, Applegate B, Molina BS, Pelham WE. (2016). Predictors of adolescent outcomes among 4-6-year-old children with attention-deficit/hyperactivity disorder. $\mathrm{J}$.

Abnorm

Psychol.125:168

Doi:10.1037/abn0000086.

Leopold DR, Christopher ME, Burns GL, Becker SP, Olson RK, Willcutt EG. (2016). Attentiondeficit/hyperactivity disorder and sluggish cognitive tempo throughout 
childhood: temporal invariance and stability from preschool through ninth grade. J Child Psychol Psych. 57:1066-74.

Doi: $10.1111 /$ jcpp. 12505.

Nilsen E. S., Varghese A., Fecica A., Xu Z. (2015). Children's production of referential statements. An examination of the role of ADHD traits and executive functioning. J. Cogn. Dev. 36 68-82. 10.1017/S0305000911000432

Rowland AS, Lesesne CA, Abramowitz AJ. (2002). The epidemiology of attention-deficit/hyperactivity disorder (ADHD): A public health view. Mental Retardation and Developmental Disabilities Research Reviews. 8:162-170.

Rumyantseva M. V. (2003). Giperaktivnost $s$ defitsitom vnimaniya: faktory riska. vozrastnaya dinamika. osobennosti diagnostiki // Defektologiya. - № 6, 22-28. [in Russian]

Sabbah W, Watt RG, Sheiham A, Tsakos G. (2008) Effects of allostatic load on the social gradient in ischaemic heart disease and periodontal disease: evidence from the Third National Health and Nutrition
Examination Survey. J Epidemiol Community Health 62, 415-20.

Semago M.M.. Semago N.Ya. (2011). Tipologiya otklonyayushchegosya razvitiya: Model analiza i eye ispolzovaniye $\mathrm{v}$ prakticheskoy deyatelnosti / Pod obshch. Red. M.M. Semago. - M.: Genzis. - 400 s. («Uchebnik XXI veka»). - ICBN 978-5-98563-242-2 [in Russian]

Semenovich A.S.

(2002).

Neyropsikhologicheskaya

diagnostika i korrektsiya $\mathrm{v}$ detskom vozraste. M.. 232 s. [in Russian]

Sirotyuk A.L. (2002).

Neyropsikhologicheskoye psikhofiziologicheskoye soprovozhdeniye obucheniya. M.. 288 s. [in Russian]

Vyigotskiy L. S. (2012). Psihologiya razvitiya cheloveka. - M.: Izd-vo Smyisl; Izd-vo Eksmo. - 1136 s., il. - (Biblioteka vsemirnoy psihologi) [in Russian]

Zinchenko Yu.P.

(2012).

Ponstneklassicheskaya

metodologiya v klinicheskoy psikhologii: nauchnaya shkola L.S. Vygotskogo - A.R. Luriya. Yu.P. Zinchenko. E.I. Pervichko // Natsionalnyy psikhologicheskiy zhurnal. - №8, 32-45. [in Russian] 